\title{
Effect of four herbicides on establishment and forage yield of Guinea grass in Puerto Rico'
}

\author{
Li C. Liu and Greicha Sievens.
}

\begin{abstract}
A field experiment was conducted at the Gurabo substation to evaluate atrazine, simazine, diuron and sebuthiuron for pre-emergence control of weeds in a Guinea grass pasture. Tebuthiuron at $3.36 \mathrm{~kg}$ ai/ha was the mosł effective herbicide in confrolling weeds, but was also very phytotoxic to the pasfure even at a lower rate. The remaining herbicides provided safisfactory weed confrol and were not as phytotoxic to Guinea grass. There were no significant yield differences among herbicide-ireated plots except for the plot with diuron. Diuron-treated plots at $3.36 \mathrm{~kg}$ ai/ha outyielded those with other herbicide treatments and the weeded check, but no significant statisfical differences in yield were observed among plots with diuron at $3.36 \mathrm{~kg}$ ai/ha atrazine at $4.48 \mathrm{~kg} \mathrm{ai} / \mathrm{ha}$ and the handweeded check.
\end{abstract}

\section{RESUAEN}

Efecto de cuarro herbicidas sobre el establecimiento $y$ el rendimiento en forraje de la yerba guinea

Se estableció un experimento de campo en un suelo Mabí arcilloso en la subestación de Gurabo para evaluar el efecto de atrazine, simazine, diuron $y$ tebuthiuron en el confrol pre-emergente de malezas en el pasto de guinea. Los efectos de estos herbicidas en distintas concenfraciones se compararon con dos testigos: desyerbo a mano $y$ sin desyerbo. El pratamiento que mejor reprimió el crecimiento de las malezas fue tebuthiuron a $3.36 \mathrm{~kg}$. p.a./ha., pero resulto fitotóxico ol pasto aun a la concentración más baja; los demás yerbicidas evaluados también controlaron satisfacioriamente las malexas. Ninguno de los ofros yerbicidas le causó daño severo por fifotoxicidad al pasto. No hubo diferencias significativas en cuanto a rendimiento de pasto en la mayoría de los frafamienfos de yerbicidas con la excepción de diuron a $3.36 \mathrm{~kg}$. p.a./ha. Las parcelas tratadas con diuron a $3.36 \mathrm{~kg}$. p.a./ha. superaron estadistícamente en rendimiento a la mayoría de los fratamientos de yerbicidas, pero fueron igual a afrazina a $4.48 \mathrm{~kg}$. p.a./ha. y el testigo desyerbado.

\section{INTRODUCTION}

Guinea grass, Panicum maximum Jacq., a native plant of tropical Africa, was introduced in Puerto Rico by merchant ships carrying slaves (6). This grass is very aggressive and competitive, subsequently establishing itself as one of the major pastures in Puerto Rico. Caro et al. (2, 9) found that guinea grass and Napier grass increased body weight of

'Manuscript submitted to Editorial Board 15 February 1991.
2Plant Physiologist, Department of Crop Protection.
${ }^{3}$ Former Research Assistant, Department of Animal Musbandry. 
cattle in a similar manner, and also that both grasses were superior to pangola grass. Weeds pose a serious management problem to local farmers in forage grass production. The pastures should be maintained weed free from their initial establishment; chemical weeding during this stage is most effective and economical for forage grass production (1). Spain and Sotomayor (8) reported that simazine and atrazine at rates of 1.8 to $7.2 \mathrm{~kg} / \mathrm{ha}$ controlled weeds effectively during the establishment of pangola grass. However, preference was given to atrazine by virtue of its less pronounced phytotoxicity. Excellent control of broadleaf weeds in two pangola grass pastures was reported by González-Ibáñez (3). He used a Tordon 101 mixture and a dicamba/2,4-D mixture. In a subsequent study, González-Ibáñez (4) found that glyphosate at 1 to $2 \%$ effectively controlled cortadera grass in pangola-guinea grass and in native grass pastures. Rodríguez-Domínguez (7) studied several herbicides for weed control in a stargrass pasture. He found that simazine was the safest compound for preemergence use. He also found that hexazinone was the best postemergence herbicide for increasing forage yields over the handweeded check. Lugo et al. (5) found that tebuthiuron at $1.68 \mathrm{~kg}$ ai/ha controlled weeds and was not too phytotoxic to stargrass. Other preemergence herbicides, such as atrazine, simazine and diuron also controlled weeds satisfactorilly for 8 weeks. There is no information on the use of herbicides for the establishment of guinea grass pastures in Puerto Rico.

The present study was thus initiated to evaluate atrazine [6-chloro- $\mathrm{N}$ ethyl-N-(1-methyl ethyl)1,3,5]; triazine (2,4-diamine); simazine (6-chloro$\mathrm{N}, \mathrm{N}$-diethyl-1,3,5); triazine (2,4-diamine); diuron [N-(3,4-dichlorophenyl)$\mathrm{N}, \mathrm{N}$-dimethylurea]; and tebuthiuron [N-5-(1,1-dimethylethyl)-1,3,4thiadiazol-2yl-N, $\mathrm{N}$-dimethylurea] for preemergence control of weeds in a guinea gxass pasture.

\section{MATERIALS AND METHODS}

The experiment was established on a Mabí clay at the Gurabo substation in July 1990. The Mabi clay belongs to the Vertic Eutropepts of the soil order Inceptisols. The soil was plowed and disc-harrowed twice. The experimental design was a randomized complete block with four replications. Each plot consisted of four rows $3.05 \mathrm{~m}$ long spaced at $70 \mathrm{~cm}$ apart. Stumps of Guinea grass clone \#3622 were obtained from the pasture grass collection at the Corozal substation and planted in 15-cm deep furrows.

Test herbicides were applied with a portable $\mathrm{CO}_{2}$ sprayer as aqueous spray broadcast over the planted guinea grass 19 July 1990, the same day of planting. A boom fitted with four Teejet \#8002 jets was used to deliver $323 \mathrm{~L} / \mathrm{ha}$ spray volume. The herbicides used included atrazine 
(AATREX), simazine (PRINCEP), diuron (KARMEX) and tebuthiuron (SPIKE). There were also weeded and unweeded check plots. Weeds were removed manually 20 August 1990. Weed control and phytotoxicity were rated at 4 and 8 weeks after planting. Weed control rating is based on a scale of 0 to 100 , where $0=$ no control and $100=$ perfect control. Phytotoxicity was evaluated on a similar scale, where $0=$ no phytotoxicity, $100=$ complete stand reduction. Guinea grass and weeds were harvested 60 days after planting, and fresh and dry weights were recorded for statistical analysis.

\section{RESULTS AND DISCUSSION}

The predominant weed species in plots were para grass [Brachiaria purpurascens (Raddi) Hehr.], pascuita (wild poinsettia) (Euphorbia heterophylla L.), pigweed (Amaranthus dubius Mart. ex Thell), morning glory [Ipomoea tiliacea (Willd) Choisy], water-primrose [Ludwigia erecta (L) H. Hara]; jungle rice [Echinochloa colona (L) Link], Mexican weed [Caperonia palustris (L) St. Hil.], bur (Urena lobata L.), garden spurge [Chamaesyce hirta (L) Millsp.], wild bean [Vigna luteola (Jacq.) Benth], soap bush (Malvastrum coromandelianum L.) and purple nutsedge (Cyperus rotundus L.). Weed control rating at 4 weeks after herbicide application indicates that tebuthiuron at either 1.68 or $3.36 \mathrm{~kg}$ ai/ha was the most effective weed control (table 1) for both broadleaf weeds and grasses. Satisfactory weed control was also attained with both rates of simazine, atrazine and diuron (table 1). Weed control rating at 8 weeks after herbicide application indicated that tebuthiuron at either

TABLE 1.-Percentage of weed control and phytotoxicity ratings at 4 and 8 weeks after herbicide application

\begin{tabular}{|c|c|c|c|c|c|c|c|}
\hline \multirow[b]{3}{*}{ Treatment } & \multirow[b]{3}{*}{ Rate } & \multicolumn{4}{|c|}{ Weed control at } & & \\
\hline & & \multicolumn{2}{|c|}{4 weeks } & \multicolumn{2}{|c|}{8 weeks } & \multicolumn{2}{|c|}{ Phytotoxicity } \\
\hline & & Broadleaf & Grass & Broadleaf & Grass & 4 week & 8 week \\
\hline & kg aitha & $\%$ & $\%$ & $\%$ & $\%$ & $\%$ & $\%$ \\
\hline Atrazine & 2.24 & 85 & 70 & 70 & 55 & 5 & 0 \\
\hline Atrazine & 4.48 & 89 & 75 & 80 & 65 & 10 & 5 \\
\hline Simazine & 2.24 & 84 & 75 & 80 & 60 & 5 & 0 \\
\hline Simazine & 4.48 & 85 & 80 & 85 & 70 & 10 & 5 \\
\hline Tebuthiuron & 1.68 & 95 & 89 & 90 & 80 & 20 & 10 \\
\hline Tebuthiuron & 3.36 & 100 & 95 & 98 & 95 & 30 & 20 \\
\hline Diuron & 1.68 & 80 & 65 & 80 & 50 & 5 & 0 \\
\hline Diuron & 3.36 & 85 & 69 & 85 & 55 & 10 & 5 \\
\hline Weeded & - & 100 & 75 & 100 & 75 & 0 & 0 \\
\hline Non-weeded & - & 0 & 0 & 0 & 0 & 0 & 0 \\
\hline
\end{tabular}


TABLE 2.-Dry and fresh weights of weeds and guinea grass at Gurabo, P.R.

\begin{tabular}{|c|c|c|c|c|c|}
\hline \multirow[b]{2}{*}{ Treatment } & \multirow[b]{2}{*}{ Rate } & \multicolumn{2}{|c|}{ Weeds } & \multicolumn{2}{|c|}{ Cruinea gxass } \\
\hline & & Fresh weight & Dry weight & Fresh weight & Dry weight \\
\hline & ka ailha & kg/ha & kg/ha & $k g / h a$ & kg/ha \\
\hline Atrazine & 2.24 & $1,607 \mathrm{bc}$ & $460 b c$ & 16,850 bc & $5,108 b c$ \\
\hline Atrazine & 4.48 & $1,436 \mathrm{bc}$ & $413 \mathrm{bc}$ & $20,916 \mathrm{ab}$ & $6,338 \mathrm{ab}$ \\
\hline Simazine & 2.24 & $1,456 \mathrm{bc}$ & 415 bc & $16,300 \mathrm{bc}$ & $4,939 b c$ \\
\hline Simazine & 4.48 & $1,177 \mathrm{bc}$ & $335 b c$ & 18,531 be & $5,611 b c$ \\
\hline Tebuthiuron & 1.68 & $1,118 b c$ & $318 \mathrm{bc}$ & 15,581 be & 4,721 bc \\
\hline Tebuthiuron & 3.36 & $15 \mathrm{c}$ & $3 c$ & $8,029 d$ & $2,434 \mathrm{~d}$ \\
\hline Diuron & 1.68 & $1,959 \mathrm{~b}$ & $560 \mathrm{~b}$ & $19,299 \mathrm{~b}$ & $5,847 \mathrm{~b}$ \\
\hline Diuron & 3.36 & $2,278 \mathrm{~b}$ & $655 \mathrm{~b}$ & $26,280 \mathrm{a}$ & 7,965 a \\
\hline Non-weeded & - & 5,614 a & $1,607 a$ & $11,833 \mathrm{~cd}$ & $3,586 \mathrm{~cd}$ \\
\hline Hand-weeded & - & $949 \mathrm{bc}$ & $272 \mathrm{bc}$ & $20,487 \mathrm{ab}$ & $6,209 a b$ \\
\hline
\end{tabular}

Means with letters in common with columns do not differ significantly at $P=0.05$.

rate showed better control of both types of weeds than did the other three herbicides. Tebuthiuron at either rate was more phytotoxic than the other three herbicides.

With reference to fresh weights, weed infestation was lowest in the tebuthiuron $3.36 \mathrm{~kg}$ ai/ha rate (table 2 ). There were no significant fresh weight differences among all other herbicide treatments. Similar trends were evident for weed dry weights (table 2).

Diuron at $3.36 \mathrm{~kg}$ ai/ha, atrazine at $4.48 \mathrm{~kg}$ ai/ha and the handweeded check gave significantly higher Guinea grass yield than the other herbicide treatments (table 2). Tebuthiuron at $3.36 \mathrm{~kg}$ ai/ha significantly reduced Guinea grass fresh and dry weight yield.

Our finding that tebuthiuron at $3.36 \mathrm{~kg}$ ai/ha is more phytotoxic than all other herbicides agrees with results obtained by Lugo et al. (5). However, the forage yield was not significantly reduced by tebuthiuron at $3.36 \mathrm{~kg}$ ai/ha in Lugo's study, whereas, Guinea grass yield was significantly reduced with tebuthiuron at $3.36 \mathrm{~kg}$ ai/ha in the present study. The resistance of stargrass to yield loss might be attributed to differences in pasture species.

\section{LITERATURE CITED}

1. Almodóvar, L., 1989. Control de malezas en pastizales 3ra. Conferencia sobre Pasto. Servicio Extensión Agricola, Univ. de Puerto Rico.

2. Caro-Costas, R., J. Vicente-Chandler and C. Burleight, 1961. Beef production and carrying capacity of heavily fertilized irrigated Guinea, Napier and pangola pastures on the semi-arid south coast of Puerto Rico. J. Agric. Univ. P. R. 45 (1): 32-6.

3. González-Ibánez, J, 1977. Control of resistant broadleaf species in Puerto Rico pastures using mixtures of 2,4-D with picloram and dicamba. J. Agric. Univ. P. R. 61:326-31. 
4. - 1984. Glyphosate for weed control in Puerto Rican pastures. I. Agric. Univ. P. R. 68: 289-96.

5. Lugo, M. de L., L. C. Liu and C. E. Ortiz, 1989. Elfect of four herbicides on the establishment and forage yield of stargrass in Puerto Rico. J. Agric. Univ. $P . R$. 73 (2): $149-53$.

6. Más E. G. and O. García-Molinari, 1990. Guía ilustrada de yerbas comunes en Puerto Rico. Servicio de Extensión Agrícola, Univ. de P. R.

7. Rodriguez-Dominguez, P., 1982. Control químico de malezas en cultivo de yerba estrella. Tesis Maestría. Univ. P. R., Recinto de Mayagüez.

8. Spain, G. L. and A. Sotomayor-Ríos, 1976. Effect of two triazine compounds on establishment and forage yield of pangola grass. J. Agric. Univ. P. R. 60 (2): 201-06.

9. Vicente-Chandler, J., F. Abruña, R. Caro-Costas and S. Silva, 1983. Producción y utilización intensiva de las forrajeras en Puerto Rico. Esta. Exp. Agric. Univ. P. R. Bol. 271. 